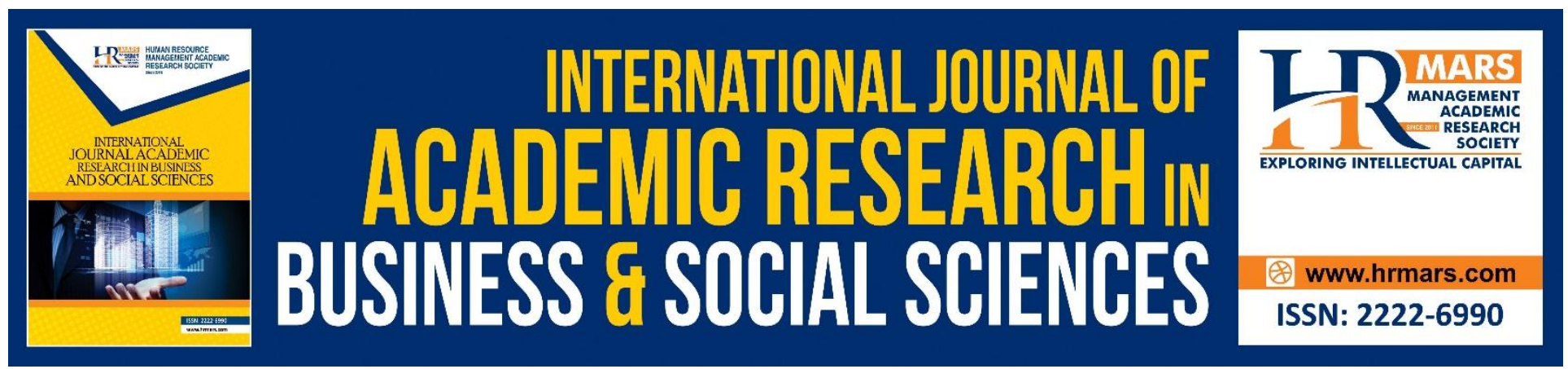

\title{
To Study the Challenges Faced By the Higher Secondary Students in Annual Examination System. A Case Study of District Matiari Colleges, Pakistan
}

Gulzar Ali Kaka, Mehboob Ali Dehraj \& Tofuque Ahmed Jamali

To Link this Article: http://dx.doi.org/10.6007/IJARBSS/v9-i3/5772

DOI: $\quad 10.6007 /$ IJARBSS/v9-i3/5772

Received: 1 Feb 2019, Revised: 16 Feb 2019, Accepted: 15 March 2019

Published Online: 30 March 2019

In-Text Citation: (Kaka, Dehraj, \& Jamali, 2019)

To Cite this Article: Kaka, G. A., Dehraj, M. A., \& Jamali, T. A. (2019). To Study the Challenges Faced By the Higher Secondary Students in Annual Examination System. A Case Study of District Matiari Colleges, Pakistan. International Journal of Academic Research in Business and Social Sciences, 9(3), 1123-1131.

Copyright: (c) 2019 The Author(s)

Published by Human Resource Management Academic Research Society (www.hrmars.com)

This article is published under the Creative Commons Attribution (CC BY 4.0) license. Anyone may reproduce, distribute, translate and create derivative works of this article (for both commercial and non-commercial purposes), subject to full attribution to the original publication and authors. The full terms of this license may be seen

at: http://creativecommons.org/licences/by/4.0/legalcode

Vol. 9, No. 3, 2019, Pg. 1123 - 1131

http://hrmars.com/index.php/pages/detail/IJARBSS

JOURNAL HOMEPAGE

Full Terms \& Conditions of access and use can be found at http://hrmars.com/index.php/pages/detail/publication-ethics 


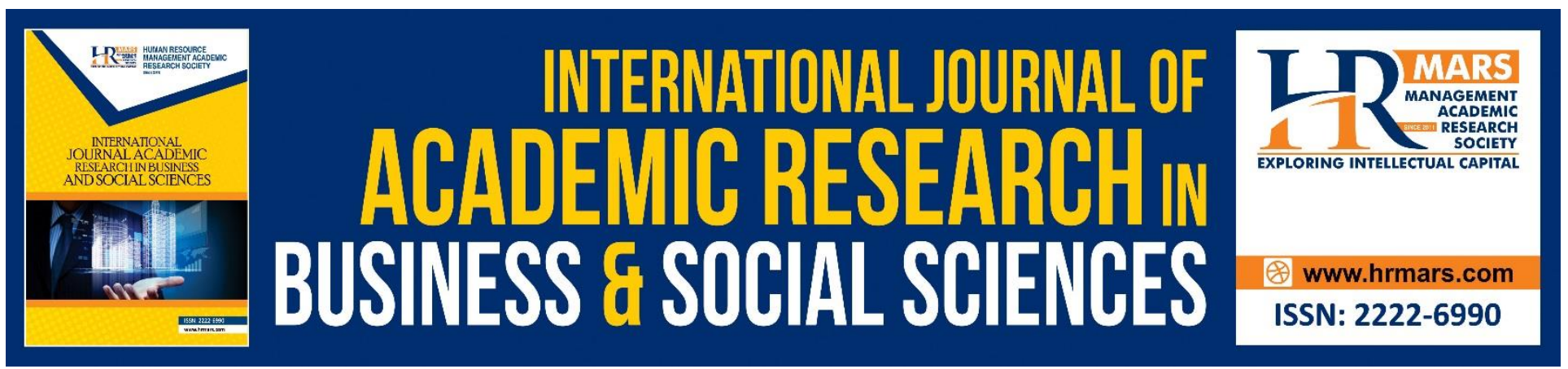

\title{
To Study the Challenges Faced By the Higher Secondary Students in Annual Examination System. A Case Study of District Matiari Colleges, Pakistan
}

\author{
Gulzar Ali Kaka
}

M.Phil Associate Shaheed Benazir Bhutto University Shaheed Benazir Abad

Mehboob Ali Dehraj

Assistant Professor, Education Department, Benazir Bhutto University Shaheed Benazir Abad

\section{Tofuque Ahmed Jamali}

M.Phil Associate Shaheed Benazir Bhutto University Shaheed Benazir Abad

\begin{abstract}
Examination system is the integrate part of educational process that assesses the students whole academic achievement. This process is so important that parents and teachers prepare students for examination whole year. Most of the schools especially in government schools there is one time written paper held for almost three hours. This assesses the whole academic achievement of a student; so the whole academic process of a student depends upon that examination. Study evaluates the challenges face by the higher secondary students in annual examination. 80 students who observed the annual and semester system were selected to response through an open ended questionnaire and 20 lecturers from Government Colleges district Matiari were interviewed. From the findings it was evaluated that annual system has failed to achieve the desired targets and it stops the intellectual and creative abilities of the students. Annual examination system just focuses the grades and marks but doesn't assess the cognitive, intellectual and creative abilities. Lecturers and students both suggested the semester system as alternate of annual system. According to both lecturers and students; the semester system activates the students whole year and it assesses the skill based learning of the students and it also enhances students' research abilities so, the semester system should be applied in higher secondary level.
\end{abstract}

Keywords: Annual Examination, semester examination, Higher secondary students, Research, intellectual abilities 


\section{Introduction}

The study addresses the flaws in annual examination system at Higher Secondary level. Annual system of examination is practiced by the Board of Intermediate \& Secondary Education working in different divisions of Sindh and they conduct onetime examination. Since the board is a neutral firm to conduct the examination and teachers and students are unaware of the rubrics of the questions which come in the question papers. Yousaf, Hashim (2012 researched on comparative analysis of semester and annual system of examinations pertains to marks difference at university level, this study focuses the multiple factors involved in the annual system of examination and challenges faced by the higher secondary students in that system. Since the inception of Pakistan, almost seven policies have been implemented. The main purposes of such policies were aimed to ensure the quality of education, but the education doesn't achieve the predetermined goals as desired. In Pakistan there is only academic performance of the students is assessed through examination. Those students are promoted to the next class who get high marks while other categories as failed and remain in that class. Students decide their future plans on the basis of pass or fail. It means that the education system revolves around an examination. This is the narrow criteria of assessment. Final examination which is the type of summative assessment is interconnected with the teaching, learning process. Farooq, Kai (2017) opines that teachers are also being assessed on the basis of such examinations. Examinations in Pakistan are generally conducted annually, semester and term system. Annual examination is conducted one time in a year, while semester examination is conducted two times in a year and term system which is implemented usually in private school is conducted three or four times in a year. Annual examinations are conducted up to intermediate level, while semester system is implemented in universities of Pakistan. In annual system usually marks are distributed as 75 or 100 per subject while in semester system 100 marks are distributed in sessional tests, presentations, assignments, midterm and final term. Annual system revolves around selected books approved by the curriculum wing. Professor Dr. Muhammad llyas khan Assistant professor in Peshawar university wrote an article in Dawn "Why students are afraid of exams" argued that schools are preparing the students only for exams and teachers, parents and students do their best to obtain good results; further the students are bound for whole year to complete the course in due time for the examination. Many researchers have studied this problem but most of them revolve around the marking or grading comparison. This study evaluates the challenges faced by the college students in annual examination system and evaluates the flaws in annual exam system. In addition to this, semester system has been analyzed as an alternate to annual examination system. Ilyas further argues that in majority of the academic institutions especially in government schools and colleges, there is only single written examination held for three hours at the end of academic year, so the students whole year depends on his performance what he does in that three hours. Due to such fear students go under depression and couldn't perform well in such examinations; incident of suicide by the student of class nine is the empirical example of above statement.

\section{Objectives}

1. To identify the challenges faced by the students in annual examination system at higher secondary level.

2. To evaluate the flaws in annual examination system at higher secondary level. 
INTERNATIONAL JOURNAL OF ACADEMIC RESEARCH IN BUSINESS AND SOCIAL SCIENCES

Vol. 9, No. 3, March, 2019, E-ISSN: 222 2-6990 @ 2019 HRMARS

3. To analyze the semester system as alternate to annual examination system at higher secondary level.

\section{Research Questions}

1. How the students face the challenges in annual examination system?

2. Why the annual examination system has failed?

3. What are the impacts of annual examination system on the students' cognitive and creative skills?

4. Can the semester system of examination be the alternate to annual examination system at higher secondary level?

\section{Scope of the study}

Scope of the study is so wide because it pertains to examination system that is being practiced in Pakistan. In Pakistan lot of flaws in examination system has been observed that need to be evaluated because it makes the future plans of a student. Students are suffering from the annual system of examination. This study will focus on the annual system of examination, the flaws and their impacts on the students. This study will also analyze semester system as an alternate to annual system of examination at higher secondary students.

\section{Problem Statement}

Examinations are directly connected to teaching-learning process that decides the students' future plans. This research will address the problem what students face the challenges in annual examination system practiced in Pakistan at higher secondary students. This research will answer the question; how the annual examination system impact on the students' cognitive abilities and creativity?

\section{Related Literature}

According to Dewey, (2012) as cited in Noddings, (2018) Education is considered reorganized, reoriented and reconstructed knowledge of behavior, skill and practice. Another researcher Darkar, (2012) as cited in Okwara, Otienoh, Murundu (2017) education is considered as recognition, skill and overall experience in life. Such broad scope of education as Ramirez, Schofer, Meyer (2018) needs a strong mechanism of assessment of students in educational institutions. Education system in the world is not same all over and it changes due to passage of time and technology. Rafiq, Ghazal, Farooqi (2007) opined that annual system in many countries mostly in west is termed as TAP (Tuition Assistance Programmed). Yousaf, A., Hashim,M.(2012) noted that in British the annual system has been implemented for more than 50 years. Pakistan has adopted the British education system so the examination system has also been practising since the inception of Pakistan. Farooq, Kai (2017) noted that Annual system of examination is traditional method of examination which has been practising in Pakistan for many years. The world has changed the outdated examination systems but Pakistan is practising same methods of assessment. According to policy on Sindh Assessment and Examinations,(2015), In Sindh different examination system are implemented for different educational levels like annual, semester and term system. Bhatti, Dehraj (2018) said that annual 
system is practised at higher secondary level, semester is practised in universities and term system is applied almost all private schools. Christy, Khushk (2009) noted that in annual examination system students just focus on selected topics and questions and students just focus on those selected questions and after examination forget those things. MoEGP theory, (2009) highlighted that in exams different skills are being assessed. Yousaf, Hashim, (2012) noted that in annual system of education there is no any feedback to the students and students are being assessed on the basis of pass or fail.

\section{Research Methods and Design}

This study is qualitative by method and descriptive by nature based on open ended questionnaire and interview method. The population area of this study is district Matiari. $\mathrm{N}=80$ students were taken as sampling80 students of district Matiari who observed semester and annual system of examination including 40 students from university of Sindh Jamshoro, 10 students from SAU Tandojam, 10 from SBBUVAS Sakrand university, 15 from MUET Jamshoro and 5 students from QUEST Nawabshah. N=20 lecturers of government colleges district Matiari including 6 lecturers from Govt College Saeedabad, 7 from Gov college Hala and 7 from Govt college Matiari. A self-made questionnaire was prepared on the basis of previous literature, observation and experience. Students have been sent an open ended questionnaire who observed both annual and examination systems. $\mathrm{N}=20$ lecturers from different government colleges of district Matiari were also interviewed. 
INTERNATIONAL JOURNAL OF ACADEMIC RESEARCH IN BUSINESS AND SOCIAL SCIENCES

Vol. 9, No. 3, March, 2019, E-ISSN: 222 2-6990 @ 2019 HRMARS

Data Collection Plan

\begin{tabular}{|c|c|c|c|}
\hline S.No & Tool for data collection & Participants Involved & Data Required \\
\hline 1 & $\begin{array}{ll}\text { Open } & \text { Ended } \\
\text { Questionnaire } & \end{array}$ & $\begin{array}{l}80 \text { students of district } \\
\text { Matiari who observed } \\
\text { semester and annual } \\
\text { system of examination } \\
\text { including } 40 \text { students } \\
\text { from university of } \\
\text { Sindh Jamshoro pass } \\
\text { out, } 10 \text { students from } \\
\text { SAU Tandojam, } 10 \\
\text { from SBBUVAS } \\
\text { Sakrand University, } 15 \\
\text { from MUET Jamshoro } \\
\text { and } 5 \text { from QUEST } \\
\text { Nawabshah pass out. }\end{array}$ & $\begin{array}{l}\text { Students' perception regarding } \\
\text { annual and semester system of } \\
\text { examinations. Challenges in annual } \\
\text { system of examination, its impacts } \\
\text { on students'cognitive and creative } \\
\text { abilities and perspective of students } \\
\text { regarding semester system of } \\
\text { examination as alternate to annual } \\
\text { system. }\end{array}$ \\
\hline 2 & Interview & 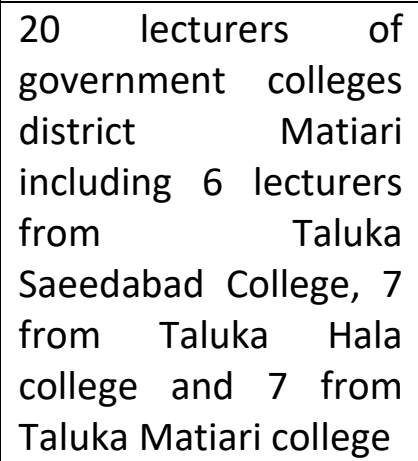 & $\begin{array}{l}\text { Flaws in annual system of education. } \\
\text { Challenges faced by the students and } \\
\text { teachers in annual system of } \\
\text { education and perspectives of } \\
\text { teachers regarding semester system } \\
\text { of education as alternate to annual } \\
\text { system of education. }\end{array}$ \\
\hline
\end{tabular}

\section{Limitations of the Study}

This study is limited to the students and lecturers of district Matiari.

\section{Open ended questionnaire used for primary data collection}

1. What are the challenges faced by the students in annual system of examination?

2. How annual system of examination impacts on students cognitive and creative abilities?

3. In which system of examination students feel easiness?

4. Which system do you feel more fruitful for a student and why?

5. Which system provides better skills opportunities to a student?

6. Which system is goal oriented?

7. Do you think annual system of examination provides conceptual understanding?

8. Do you find semester system as alternate to annual system of examination at higher secondary level?

9. Why the students look towards unfair means in annual examination?

10. Which system is the best system of examination? 


\section{Major Key Findings Obtained From Interviews Pertains To Lecturers}

$>$ It is difficult to complete the course due to less time.

$>$ Due to lack of proper monitoring attendance ration is negligible.

$>$ Due to the lack of authority to the teacher, they are unable to control absenteeism.

$>$ Annual examination comes once in a year so the students are passive all the year.

$>$ If a teacher gives any assignment to the students they don't complete it properly because they consider it noncredit.

$>$ As the examination is conducted by the BISE annually so the teachers try to focus on those questions which are repeated in almost last five years unsolved papers.

$>$ Students at the time of examination memorize repeated questions for obtaining good marks.

$>$ Conceptual study of the students severely affected.

$>$ Due to selected books assigned to particular subject students don't want to refer any other books related to topics.

$>$ Students' research potential is severely affected.

$>$ Due to the burden of whole year study students try to an alternate source like copy or any other unfair means.

$>$ Due to annual system of examination students feel burden so the teachers also try to make concise notes from selected topics.

$>$ Annual system of examination forces the students towards rote learning.

$>$ Innovative teaching becomes fail in annual system because the examination system assesses only knowledge of the students not skills or intellectual abilities.

$>$ There is no any proper feedback from the board system so the students the performance only depends upon the vague paper.

\section{Major Key Findings Obtained from Open Ended Questionnaire}

$>$ Annual system of examination makes students passive.

$>$ Annual examination only assesses the memory power of the students.

$>$ Time duration is lengthy and it is impossible to memorize the whole year course.

$>$ Students knows that there is only one paper of a subject that make him pass so he takes stress that impacts on his cognitive and creative abilities.

$>$ Due to the disturbance of many committees visit students feel fear of exams and they even forget things.

$>$ Annual system of examination is the major cause of cheating or any unfair means in examinations.

$>$ In semester system the marks are distributed so the teacher is free to assess the students' skills, creativity and knowledge through presentations, assignments, projects etc.

$>$ Assessment in semester system goes on continuously so the students are active whole the year.

$>$ Course doesn't revolve on one book but students have to search that topic from different sources.

$>$ Students show their expertise and skills freely because different opportunities are being provided by the teachers. 
$>$ Students know that what I present would be credited with marks so he focuses on the performance rather that rote learning.

$>$ Teachers provide feedback where a student makes any mistake or where he needs guidance.

$>$ Due to the feedback system by teachers; students tries to make less errors and perfection level increases.

\section{Discussion}

From the findings major flaws have been filtered out in annual system of education. From the lecturers and students' responses it is concluded that annual system of education has failed to achieve the desired targets. It rather than assessing the intellectual and creative abilities assess the rote learning of the students. These factors force the students to copy culture or other unfair means to pass the examination. Prof: Dr Muhammad Ilyas Khan in his article "Text books that kill the creativity" in dawn summarized the rote questions that only assess the memory powers of the students. Due to annual examination system the Students are becoming exam robots and teachers feed the knowledge in those robots so that on the day of exam they perform well. Both lecturers and students acknowledged the semester system as alternate to annualsystem.

(Yousaf, Hashim, M. (2012); Rafiq, Ghazal, Farooqi. (2007); Bhatti, Dehraj, (2018); Cheung, Fok, Gou. (2016) have also supported the above findings.

\section{Conclusion}

Study found the major flaws in annual system of examination being observed at higher secondary level. Students face lot of challenges in this system. Annual system of examination has lessened the intellectual and research abilities of the students because they only revolve around a text book. From the responses of students obtained through questionnaire; it is concluded that students feel lot of difficulties because it only assesses the students' memory not creativity and skills. Due to that type of assessment students look towards the unfair means to attempt the paper. From the findings the students who observed both system i.e. annual and semester take interest in semester system of examination they want to replace annual system with semester system. Students prefer semester system of examination because they consider it the skill based assessment. Semester system of assessment has been suggested as alternate to annual system. Annual system just focuses on paper per subject in a year and it stresses upon the students. Most of the students feel burden in annual system because of whole course work assessment in one paper. It is dire need of situation that with the passage of time the new innovative methods are being introduced so the assessment systems produce intellectual and creative persons rather than exam robots.

\section{Recommendations}

From the findings lot of challenges have been observed that categorically deny the annual system of examination. Students are forced to revolve around subject text books that make a boundary in the mind of a student. The pressure of exam system, pressure of parents and teachers squeezes the child's own ability to think and they take stress of that system resulting he looks to another unfair means to attempt the paper or commit suicide it is recommended that annual examination system should be replaced with semester system. Annual system produce only exam robots so the higher 
authorities need to construct examination review committee so that annual system of examination may be reviewed at higher secondary level. Higher secondary level is the link to university level and students need to be familiar with the university system, so annual system need to be replaced with semester system. If the annual system would be replaced with the semester system; the students would be free to think, to observe, they focus on creative skills rather than rote learning. Research element would be inculcated among the students and cheating would be eliminated which is the burning issue at secondary and higher secondary level.

\section{References}

Awan, A. G., Zia, A. (2015). Comparative Analysis of Public and Private Educational Institutions: A case study of District Vehari-Pakistan. Journal of Education and Practice, 6(16), 122-130.

Bhatti, A. W., Dehraj, M. A. (2018). A Study Of Annual Examination System In Sindh At Grade Eight Level In Pakistan. Educational Research International Vol.7(1).

Cheung, L. T. O., Fok, L., Gou, G. R. (2016). Students' academic performance in environmental studies: an empirical study of different groups of secondary school graduates. International Research in Geographical and Environmental Education, 25(3), 211-225.

Farooq, M. S., Kai, Y. T. (2017). A Review of Pakistan School System. Journal of Education and Practice, 8(4), 97-101.

Herani, G. M., Mugheri, M. S., Advani, A. (2015). Measuring the endeavors' Impact of Quality Enhancement Cell on Quality of Higher Education system in Pakistan. A case of Private and Public Universities in Pakistan. Journal of Management for Global Sustainable Development, 1(1), 37-39.

Khan, N., Hussain, K. S., Bano, S. S. (2017).Public Private Partnership on Development of Education in Pakistan.

Murundu, H. H., Okwara, M. O., Otienoh, R., Murundu, Z. O.(2017).Factors Influencing Selection and Use of Media for Christian Religious Education Teaching and Learning.

Noddings, N. (2018). Philosophy of education. Routledge.

Rafiq, R., Ghazal, S., Farooqi, Y. N. (2007). Test anxiety in students: semester's vs. annual system. Journal of Behavioural Sciences, 17(1/2), 79.

Ramirez, F. O., Schofer, E., Meyer, J. W. (2018). International tests, national assessments, and educational development (1970-2012). Comparative Education Review, 62(3), 344-364.

Yousaf, A., Hashim, M. (2012). A case study of annual and semester systems of examination on Government College of management sciences, Peshawar, Pakistan. International Journal of Academic Research in Business and Social Sciences, 2(9), 53. 